\title{
'ANGLO-AMERICAN’ MILITARY JUSTICE SYSTEMS AND THE WAVE OF CIVILIANIZATION: WILL DISCIPLINE SURVIVE?
}

\author{
Stephen S. Strickey
}

\section{Keywords}

Military justice, military courts, civilianization

In 1980, the esteemed American jurist Robinson Everett published an article with the somewhat visionary title 'Some Comments on the Civilianization of Military Justice.' Civilianization denotes the reform of traditional aspects of a military justice system to resemble its civilian criminal justice counterpart. ${ }^{2}$ The notion of civilianization contemplated by Judge Everett over 30 years ago was quite different, however, from the reform, in the 1990s and beyond, within a number of 'Anglo-American'3 military justice systems, in particular those 'founded ... in Great Britain and her former colonies. ${ }^{4}$ While various articles in US military

\footnotetext{
Lieutenant-Colonel, Office of the Judge Advocate General (Canada). LCol Strickey B.A., L.L.B, L.L.M., is currently the Director of Law/Military Justice Strategic where his responsibilities include developing a strategic military justice vision for the Office of the JAG. This paper is based upon his work at Duke University School of Law in 2012, where he graduated with an LLM magna cum laude and was a staff editor on the Duke Journal of Comparative and International Law. LCol Strickey has also held various postings in the Office of the JAG including two operational deployments to Afghanistan in 2006 and 2009 respectively. The author is very grateful to the leadership and scholarship of three mentors: Major General (ret'd) Charles Dunlap, Professor of Law, Duke University; Colonel Patrick Gleeson, Deputy JAG Operations; and Colonel Michael Gibson, Military Judge. The views of the author that are expressed in this article are solely those of the author in his personal capacity and should not be attributed to the Office of the Judge Advocate General, the Department of National Defence, the Canadian Forces or the Government of Canada. This paper is based on a presentation given at the Cambridge Journal of Comparative and International Law Conference in May 2013.

1 See R O Everett, 'Some Comments on the Civilianization of Military Justice' (1980) Army Lawyer 1.

2 Ibid, 3; M Groves, 'The Civilianization of Australian Military Law' (2005) 28 UNSW LJ 364, 366-367. See generally E F Sherman, 'The Civilianization of Military Law' (1970) 22 Me LR 3.

3 A W Dahl, 'Address at the Global Military Appellate Seminar (Yale Law School): International Trends in Military Justice' (Apr. 1 2011), <http://www.law.yale.edu/2011-04_Interna tional_trends.pdf> [accessed 3 July 2013].

${ }^{4}$ Ibid.
}

Copyright $\odot$ the Author(s).

This work is licensed under a Creative Commons Attribution-NonCommercial-NoDerivs 3.0 License. 
law circles may have coined the term 'civilianization,' ${ }^{5}$ the US stands as one of the last bastions of the 'Anglo-American'6 military justice systems to withstand the pressure from various external sources to shift toward a more civilianized system. ${ }^{7}$

At the centre of the military justice system is the commanding officer. As one author states, 'first and foremost, military justice is one of the primary tools a military commander has to maintain discipline within the ranks.' 8 This sentiment is echoed by America's allies in the UK's Military Service Law Manual, which refers to the commanding officer as the 'heart' of discipline ${ }^{9}$ with similar views held in Canada and Australia. ${ }^{10}$

While the military justice systems of numerous militaries share this rationale, recent history questions this premise. Other than the US, which has resisted the wave of reform exhibited in allied military justice systems as of the 1990s, the modern view of discipline in Australia and the UK has resulted in the military justice system trending closer towards a civilianized model, with Canada retaining the military character of the system. ${ }^{11}$ In particular, the role of the

5 See generally Everett, above n 1; Sherman, above n 2; D Karlen, 'Civilianization of Military Justice: Good or Bad' (1973) 60 Mil LR 113; and KJ Hodson, 'Military Justice: Abolish or Change?' (1973-74) 22 Kan LR 31 (where the authors discuss civilianization in the American military justice system).

${ }^{6}$ Dhal, above $\mathrm{n} 3$.

7 See V Hansen, 'Changes in Modern Military Codes and the Role of the Military Commander: What Should the United States Learn from this Revolution?' (2008) 16 Tul J Int'l \& Comp L 419, 421-422 (where the author describes the 'revolution' in the Canadian and UK military justice system during the 1990s). See generally E R Fidell, 'A World-Wide Perspective on Change in Military Justice' (2000) 48 Air Force L Rev 195.

${ }^{8}$ Hansen, above $\mathrm{n} 7,423$.

9 See Ministry of Defence (UK), Manual of Service Law (2013) 1-1-2, <http://www.mod.uk/NR/rdonlyres/59A700FA-13A8-4D2B-BE91-6D87BD3966B3/0/Vol1SectionlVer1.pdf> [accessed 3 July 2013] (Manual of Service Law).

${ }^{10}$ See Office of the Judge Advocate General (Canada), Military Justice at the Summary Trial Level (2011) p 1-13, <http://www.forces.gc.ca/assets/FORCES_Internet/docs/en/jag/manual-mil-jussummary-trial-level.pdf> [accessed 7 December 2013]. For Australia, see Senate Foreign Affairs, Defence and Trade References Committee, 'The Effectiveness of Australia's Military Justice System' (June 2005) ch 2, <http://www.aph.gov.au/Parliamentary_Business/Committees/Senate_Committees?url=fadt_ctte/completed_inquiries/2004-07/miljustice/report/index.htm> [accessed 4 July 2013] (Australia Senate Report).

${ }^{11}$ See A Lyon, 'After Findlay: A Consideration of Some Aspects of the Military Justice System', in E R Fidell \& D H Sullivan (eds), Evolving Military Justice (2002) 218, 228; R Jones, 'Recent Reforms to the Australian Defence Force Discipline System' (2007) 7 NZ Armed F LR 77, 78; D Goetz, 'Bill C-25-An Act to Amend the National Defence Act' (1998), <http://publications.gc.ca/collections/Collection-R/LoPBdP/LS/361/c25-e.htm\#(6)text> [accessed 4 July 2013] (legislative sum- 
commanding officer in the aforementioned Commonwealth countries has been significantly reformed in the court martial process. ${ }^{12}$ In the US, the role of the commanding officer in the military justice system has been under scrutiny by legislators and commentators alike, with the Secretary of Defense recently recommending to Congress that certain powers of the commanding officer be eliminated. ${ }^{13}$

This paper argues that while the US has been criticised for not 'modernizing' its military justice system, ${ }^{14}$ its system arguably represented the 'first wave' of civilianization in 'Anglo-American' military justice systems in the 1950's, with the UK, Canada and Australia following with reforms in the 1980's and 1990's. ${ }^{15}$ While the latter three countries have been struggling to balance the disciplinary requirements of a military justice system with constitutional requirements and judicial decisions, the US' system has remained surprisingly static. ${ }^{16}$ However, recent events suggest that the American military justice system could be entering

mary of Bill C-25).

12 See generally J S T Pitzul \& J C Maguire, 'A Perspective on Canada's Code of Service Discipline' (2002) 52 Air Force L Rev 1; Judge Advocate General, Defence Force Discipline Act: Report for the Period 1 January to 31 December 2005 (2005) paras 62, 82 (c) (Australian JAG Report 2005); A D Mitchell \& T Voon, 'Justice at the Sharp End: Improving Australia's Military Justice System' (2005) 28 UNSW LJ 396; G R Rubin, 'Why Military Law? Some United Kingdom Perspectives' 26 U Queensland LJ (2007) 353, 355-356.

${ }^{13}$ See A Mulrine, 'Marine demoted to private to end Haditha trial. Did military justice work?', The Christian Science Monitor, 24 January 2012, < aditha-trial.-Did-military-justice-work> [accessed 7 December 2013]; Memorandum from Leon Panetta, Secretary of Defense to the Secretaries of the Military Departments, the Chairman of the Joint Chiefs of Staff and the Chair of the Defense Legal Policy Board, 30 July 2012 (on file with author) (Panetta letter); Letter from Chuck Hagel, Secretary of Defense to Barbara Boxer, US Senator, 7 March 2013 (on file with author) (Hagel letter); see also C Savage and E Bumiller, 'An Iraqi Massacre, a Light Sentence and a Question of Military Justice', NY Times, 27 January 2012, <http://www.nytimes.com/2012/01/28/us/aniraqi-massacre-a-light-sentence-and-a-question-of-military-justice.html $>$ [accessed 2 November 2013]; News Release, US Department of Defense, 'Statement from Secretary Hagel on Sexual Assault Prevention and Response’, 8 April 2013, <http://www.defense.gov/Releases/Release.aspx?ReleaseID=15917> [accessed 2 November 2013] (Hagel statement).

${ }^{14}$ See K J Barry, 'The Cox Commission: Recommendation for the Modernization of the US Military Justice System', NZ Armed F LR 42, 45-46 (2001); see generally K J Barry, 'A Facelift (and much more) for an Ageing Beauty: The Cox Commission Recommendations to Rejuvenate the Uniform Code of Military Justice' (2002) LRev MSU-DCL 57 (where the author outlines the recommendations from the Cox Commission I).

15 See generally Everett, above n 1; Sherman, above n 2; Hansen, above $n 7$ (where the authors discuss changes to the US system); Pitzul \& Maguire, above n 12 (Canada); F B Healy, "The Military Justice System in Australia' (2002) 52 Air Force L Rev 93 (Australia); Rubin, above n 12 (UK).

16 See Barry (2001), above n 14, 45. 
its second wave of civilianization, in which it will undoubtedly look to its allies for comparative models. ${ }^{17}$

The paper is divided into three parts. Part A will briefly outline the impact of civilianization on the military justice systems in the UK, Canada, Australia and the US, respectively. Part B will examine how civilianization has affected the involvement of the chain of command in the court martial process. Finally, Part C will offer recommendations for legislators, legal officers and policy experts when considering comparative models as the basis for possible reforms.

\section{The impact of civilianization}

\subsection{The United Kingdom}

\subsubsection{The genesis of the 'Anglo-American' military justice system}

Perhaps expectedly, the very term 'courts martial' derives its name from the evolution of English military jurisprudence. ${ }^{18}$ Prior to 1521, military discipline was the responsibility of the Court of the High Constable and Earl Marshal. ${ }^{19}$ Eventually, this jurisdiction became the 'Court of the Marshal' (when the holder of the Office of the Lord High Constable was beheaded in 1521). ${ }^{20}$ In 1666, the Judge Advocate General was given the task to supervise 'courts-martial' for the British Army, with the Judge Advocate of the Fleet performing the same task for the Navy (from 1661). ${ }^{21}$

The enactment of the Mutiny Act in 1689 proved to be 'the beginning of an era ${ }^{22}$ in that it codified military offences in statutes (mutiny and desertion) and provided a rudimentary court martial procedure to try offenders. ${ }^{23}$ From 1689 to 1881, successive Articles of War were promulgated by the Crown to

\footnotetext{
${ }^{17}$ See generally, ibid (where the US military justice system is under scrutiny).

${ }^{18}$ See Judiciary of England and Wales, Military: The constitutional position, function and history of the Judge Advocate General (JAG), <http://www.judiciary.gov.uk/about-the-judiciary/the-judiciaryin-detail/jurisdictions/military-jurisdiction\#headingAnchor2> [accessed 14 October 2013] (UK $J A G$ website).

${ }^{19} \mathrm{Ibid}$

${ }^{20} \mathrm{~J}$ Stewart-Smith, 'Military Law: Its History, Administration and Practice?' (1975) 1 Mil LR 25, 28.

${ }^{21}$ See UK JAG Website, above n 18; but see R Lorenzo Ponce de Leon, "The Coming of Age of Military Law and Jurisdiction in the English-Speaking Countries' (2010) 19 Mil L \& L War Rev 263, 274-275 (where the author describes the unique role of the JAF and the Chief Naval Judge Advocate).

${ }^{22}$ Stewart-Smith, above n 20, 26.

${ }^{23}$ Ibid, 26-27.
} 
work in conjunction with the Mutiny Act to ensure the discipline of soldiers in times of conflict. ${ }^{24}$ The 1881 Army Act and the 1866 Naval Discipline Act were the statutory bases for military justice until each of the services promulgated their respective Discipline Acts in 1955 (Army and Air Force) and 1957 (Navy) respectively: ${ }^{25}$ 'much of each of them is devoted to the disciplinary code of the service to which it relates and the setting up and procedure of the tribunals to try offences against it.' ${ }^{26}$

While the military justice system '[enjoyed] a longstanding detachment from civilian legal developments and norms, ${ }^{27}$ various decisions from the European Court of Human Rights (ECtHR) ${ }^{28}$ from the 1990s onwards paved the way for substantial modifications to the British military justice system. ${ }^{29}$

\subsubsection{Findlay and the era of civilianization}

Arguably, the civilianization era in the UK began in 1997 with the decision of the ECtHR in Findlay v United Kingdom. ${ }^{30}$ The Court examined if the court martial, as it was composed in 1991, satisfied the right to be tried before an independent and impartial tribunal in accordance with Article 6(1) of the European Convention of Human Rights (ECHR). ${ }^{31}$ Given that a senior ranking officer convened the court martial and selected the prosecutor, the Court determined that the tribunal was not 'free of personal prejudice or bias' ${ }^{32}$ and not objectively impartial. ${ }^{33}$ The outcome of the Findlay decision was the enactment of the 1996 Armed Forces Act (AFA) that served to 'make sweeping changes to the British courts-martial system.' ${ }^{34}$

\footnotetext{
${ }^{24}$ Ibid.

${ }^{25}$ Ibid, 25; see also S Rowlinson, 'The British System of Military Justice' (2002) 52 AF LR 17, 18.

${ }^{26}$ See Stewart-Smith, above n 20, 25.

${ }^{27}$ G R Rubin, 'United Kingdom Military Law: Autonomy, Civilianization, Juridification' (2002) 65 $M L R 36,44$.

${ }^{28}$ European Convention for the Protection of Human Rights and Fundamental Freedoms, 4 November 1950, 213 UNTS 221 (ECHR); see generally European Court of Human Rights, Questions and Answers, <http://www.echr.coe.int/Documents/Questions_Answers_ENG.pdf> [accessed 14 October 2013].

${ }^{29}$ See De Leon, above n 21, 270.

${ }^{30}$ See Findlay $v$ The United Kingdom, no 22107/93, Judgment of 25 February 1997, ECHR 1997-I, no. 30.

${ }^{31}$ Ibid; see also ECHR, above n 28, Art 6(1).

${ }^{32}$ De Leon, above n 21, 271-272; see also H McCoubrey, 'Due Process and British Courts Martial: A Commentary Upon the Findlay Case' (1997) 2 J Armed Conflict L 83, 86-87.

${ }^{33}$ De Leon, above n 21, 272.

${ }^{34}$ McCoubrey, above n 32, 87; see also Armed Forces Act 1996, c. 46 (UK) (AFA 1996).
} 


\subsubsection{The 1996 AFA and further challenges}

The 1996 AFA resulted in four major changes to the British military justice system. ${ }^{35}$ First, the ability of the chain of command to approve or revise sentences was repealed. ${ }^{36}$ Second, the judge advocate was given a more prominent role as 'a member of the court martial' ${ }^{37}$ and their rulings on law were now binding on the panel. ${ }^{38}$ Third, the ability of the convening officer to select the prosecutor was removed in favour of a 'Prosecuting Authority'-a senior legal officer who determines the charges and the type of court martial. ${ }^{39}$ Finally, the ability of the convening authority to select the members of the panel was substituted with a 'court administration officer. ${ }^{40}$ While the 1996 AFA did not amalgamate the three services, the legislation modified the respective Army, Air Force, and Naval Discipline Acts in the aforementioned fashion. ${ }^{41}$

The changes advanced in 1996 did not serve to lessen the ECtHR's criticisms of the British military justice system. In addition to unfavourable judgments in 1999 and 2002, the Court rendered two rulings in December 2003 that were critical of the tri-service aspect of the military justice system. ${ }^{42}$ For instance, in Grieves $v$ the United Kingdom, the Court was critical of the Royal Navy's court martial system (under the Naval Discipline Act of 1957) due to the role of the Chief Naval Judge Advocate (CNJA) in appointing judge advocates for (naval) courts martial. ${ }^{43}$ Despite the changes enacted in 1996, further reforms would be required.

\footnotetext{
${ }^{35}$ See McCoubrey, above n 32, 87.

${ }^{36}$ Ibid; see also AFA 1996, above n 34, s 15.

${ }^{37}$ McCoubrey, above n 32, 87; see also AFA 1996, above n 34, sch.1, Part III, ss. 19 (Army), 35 (Air Force), 51 (Navy).

${ }^{38} \mathrm{Ibid}$.

${ }^{39}$ McCoubrey, above n 32, 87; see also AFA 1996, above note 34, sch. 5, Part II.

${ }^{40}$ McCoubrey, above n 32, 87; see also AFA 1996, above note 34, sch.1, Part III, ss. 19 (Army), 35 (Air Force), 51 (Navy).

${ }^{41}$ McCoubrey, above n 32, 87.

${ }^{42}$ See De Leon, above n 21, 272-274; see also Cooper v United Kingdom, no. 48843/99, 16 December 2003, ECHR 2003-XII.

${ }^{43}$ Ibid; see also Grieves v United Kingdom, no 57067/00, 16 December 2003, ECHR, 2003-XII.
} 


\subsubsection{The 2006 Armed Forces Act: trending towards a civilian system}

The death knell for the traditional British military justice system may have been the 2006 ECtHR decision in Martin v United Kingdom. ${ }^{44}$ In this case, the accused was an 18 year-old dependent of a military member stationed in Germany, who was accused of murder. ${ }^{45}$ The ECtHR, using the Findlay rationale, determined that the court martial lacked independence and was not sufficiently impartial, thus violating Article 6(1) of the ECHR. ${ }^{46}$

With the myriad of ECtHR decisions in its wake, the British Parliament was left with no choice but to reform the military justice system. ${ }^{47}$ One year prior to the Martin decision, the government tabled the Armed Forces Bill 2006 that received Royal Assent in November 2006, but the bill did not come into force until October 2009. ${ }^{48}$ The resulting Armed Forces Act 2006 (AFA 2006) served, inter alia, to replace 'traditional' ad hoc courts martial with a standing court. ${ }^{49}$ The 'new' court martial is comprised of a civilian judge advocate and a panel of three, five or seven (military) members depending on the offence charged. ${ }^{50}$ It is a court of record' similar to a civilian criminal court. ${ }^{51}$ The panel votes (by majority) on guilt or innocence. ${ }^{52}$ The judge advocate does not vote in matters regarding the guilt or innocence of the accused but does have a vote regarding sentence if there is an equality of votes. ${ }^{53}$ The court martial has powers of punishment ranging from imprisonment for life to minor punishments. ${ }^{54}$ Consistent with earlier reforms, there is a right of appeal to the Court Martial Appeal Court and, ultimately, to the Supreme Court. ${ }^{55}$ Finally, the reforms created an independent Director of Service Prosecutions (DSP); where 'there is no requirement that the DSP be a member of [Her Majesty's] forces'. The current DSP is a civilian. ${ }^{56}$

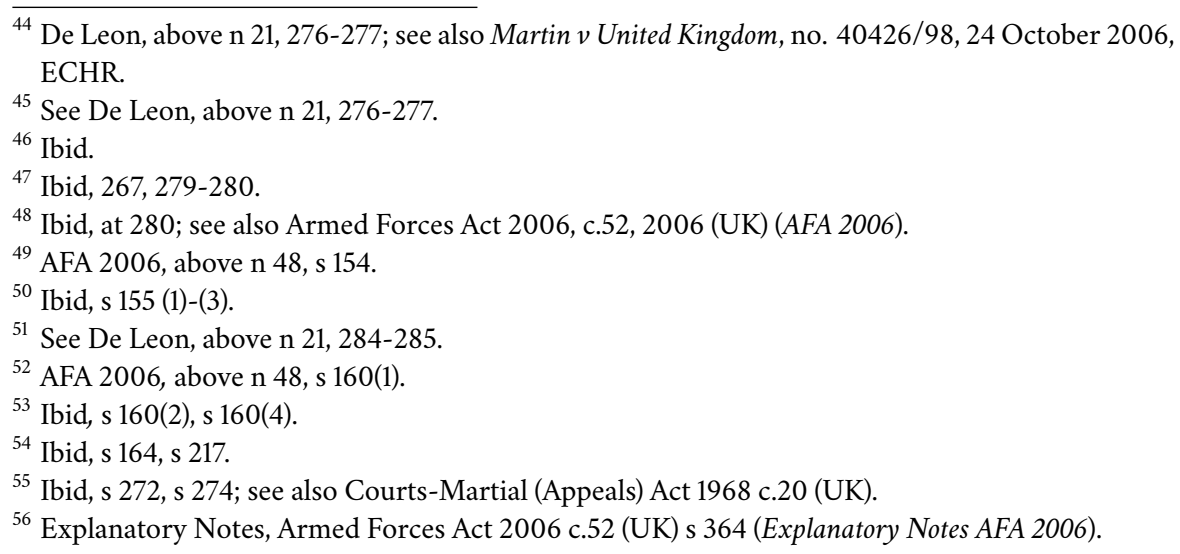




\subsection{Canada}

\subsubsection{Inheriting the British system}

It is not surprising that Canada, similar to the other British colonies, adopted its military justice system from the UK. ${ }^{57}$ Indeed, "[i]t has been suggested that the early history of the Canadian military justice system is, in effect, the history of British military law' ${ }^{58}$ Following the foundation of Canada in 1867, the Militia Act 'adopted the British Army model for a code of discipline.59 Such legislation was logical given the presence of British troops in Canada both prior to and following confederation. ${ }^{60}$

From the promulgation of the Militia Act in 1868 until the conclusion of World War II, Canada utilised the British military discipline system in each of its armed forces (Army, Navy, Air Force). ${ }^{61}$ It was not until 1950 that Canada formed a uniform code of military justice in the National Defence Act (NDA) ${ }^{62}$

\subsubsection{The National Defence Act and the Charter: Canadianization of the British system}

The NDA retained the two-tier system of military justice inherited from the British: summary trials and courts martial. ${ }^{63}$ The period from 1950 until the mid-1980's represented a relatively calm era in military justice with little legislative action. ${ }^{64}$ This relative tranquility, however, would dramatically change with the enactment of the Canadian Charter of Rights and Freedoms in $1982,{ }^{65}$ which guarantees 'fundamental legal, equality, and language rights for all individuals as Canadian citizens, including fairness in criminal and penal matters before the courts. ${ }^{66}$ While the advent of the Charter led to a significant shift from the traditional British military model, ${ }^{67}$ further reform was in the offing

\footnotetext{
${ }^{57}$ See generally Pitzul \& Maguire above $n$ 12, 2.

${ }^{58} \mathrm{Ibid}, 2$.

${ }^{59} \mathrm{Ibid}, 3$.

${ }^{60}$ Ibid, $2-3$.

${ }^{61}$ Ibid, $3-5$.

${ }^{62}$ Ibid, 5.

${ }^{63}$ Ibid, $3,6$.

${ }^{64} \mathrm{Ibid}, 6$.

${ }^{65}$ The Constitution Act, 1982, being schedule B to the Canada Act 1982 (UK), c.11 (Charter).

${ }^{66}$ C Madsen, Another Kind of Justice: Canadian Military Law from Confederation to Somalia (1999) 132.

${ }^{67}$ See Pitzul \& Maguire, above n 12, 8.
} 
as a consequence of the most important judicial decision in Canadian military justice history-Regina $v$ Genereux. ${ }^{68}$

\subsubsection{Rv Genereux: reinforcement of a sui generis military justice system}

The Genereux decision by the Supreme Court of Canada was the first Charter challenge to the traditional court martial system. ${ }^{69}$ At issue was section 11(d) of the Charter-the right to be tried before an impartial tribunal-in relation to courts martial. ${ }^{70}$ The Court determined that, among other things, the ability of the chain of command to appoint the prosecutor (on recommendation from the Judge Advocate General) and members of the court martial panel violated the Charter's guarantee of a court's independence. ${ }^{71}$ Importantly, however, the Supreme Court acknowledged the military justice system as a separate system of justice. $^{72}$

\subsubsection{Somalia and Bill C-25: The modern era of Canadian military justice}

The Genereux decision was followed by a dark incident in Canadian military history. During a UN-sponsored mission to Somalia in 1993, Canadian soldiers captured, tortured and killed a Somali teenager. ${ }^{73}$ The result was a firestorm in Canada that led to the disbandment of the Canadian Airborne Regiment and a public inquiry and other reports that examined, inter alia, the military justice system. ${ }^{74}$ This resulted in the drafting of Bill C-25, an Act to Amend the National Defence Act, in $1998 .^{75}$ Bill C-25 'marked the first substantial amendments to the Code of Service Discipline in a post-Canadian Charter of Rights and Freedoms environment. ${ }^{76}$ Reforms included the statutory recognition of the role and functions of the Judge Advocate General, while removing its power to

${ }^{68} R v$ Genereux, [1992] 1 S.C.R. 259 (where the Supreme Court of Canada reinforces the need for a separate military justice system); See Pitzul and Maguire, above n 12, 9.

${ }^{69} \mathrm{C}$ Madsen, Military Law and Operations (Vol 6, 2011) 2-6.

${ }^{70}$ See Charter, above n 65, s11(d).

${ }^{71}$ See Genereux, above n 68, 302-325.

72 Ibid, 293.

${ }^{73}$ See Madsen, above n 69, 1-36 to 1-37.

${ }^{74}$ Madsen, above n 66, 144-150; see also Madsen, above n 69, 1-36 to 1-39.

${ }^{75}$ See An Act to Amend the National Defence Act, S.C. 1998, c.35 (Bill C-25).

${ }^{76}$ See Madsen, above n 69, 1-38. 
review any finding of a court martial to ensure legality; the establishment of an independent Director of Military Prosecutions and Director of Defence Counsel Services; and the abolishment of the death penalty. ${ }^{77}$ The position of Court Martial Administrator was created to statutorily eliminate the ability of the chain of command to appoint panel members. ${ }^{78}$

Following the enactment of Bill C-25, the military justice system was subject to an independent review in 2003 by a former Chief Justice of the Supreme Court of Canada. ${ }^{79}$ The former Chief Justice stated that 'Canada has developed a very sound and fair military justice framework in which Canadians can have trust and confidence, ${ }^{80}$ and made 88 recommendations, approximately 50 of which dealt with the military justice system. ${ }^{81}$ Based on the aforementioned recommendations, the government tabled legislation in 2006, 2008 and 2010 but all three bills died on the Order Paper. ${ }^{82}$ A subsequent bill, Bill C-15, is currently under consideration before the Canadian Parliament. ${ }^{83}$

Following the introduction of Bill C-15 in Parliament, a second independent review of the military justice system was undertaken by retired Chief Justice Patrick LeSage of the Ontario Superior Court of Justice that was tabled in Parliament in June 2012. ${ }^{84}$ In terms of the military justice system, the report supported the previous findings of the importance and uniqueness of the military justice system" ${ }^{85}$ and, quoting the Lamer Report, affirmed that '[the] military justice system is sound, but some modifications will assist in ensuring its continued strength and viability. ${ }^{86}$

\footnotetext{
${ }^{77}$ See Goetz, above n 11.

${ }^{78}$ Ibid.

${ }^{79}$ A Lamer, The First Independent Review by the Right Honourable Antonio Lamer of the Provisions and Operations of Bill C-25, An Act to Amend the National Defence Act and to make consequential amendments to other Acts (3 September 2003) (Lamer Report).

${ }^{80}$ Ibid, 1 .

${ }^{81}$ Ibid, 112-119.

${ }^{82}$ An Act to Amend the National Defence Act, 2006, H.C. Bill C-7 (Canada) (Bill C-7); An Act to Amend the National Defence Act, 2008, H.C. Bill C-45 (Canada) (Bill C-45); An Act to Amend the National Defence Act and to Make consequential Amendments to Other Acts, 2010, H.C. Bill C-41 (Canada) (Bill $C-41)$.

${ }^{83}$ An Act to amend the National Defence Act and to make consequential Amendments to Other Acts, 2011, H.C. Bill C-15 (Canada) (Bill C-15); see also, Office of the Judge Advocate General, Department of National Defence, Amendments to the National Defence Act: Background and Amendment Highlights (October 2011).

${ }^{84}$ P LeSage, Report of the Second Independent Review Authority to the Honourable Peter G. Mackay, Minister of National Defence (December 2011) (LeSage Report).

${ }^{85}$ Ibid, 10.

${ }^{86} \mathrm{Ibid}, 12$.
} 


\subsection{Australia}

\subsubsection{The early years}

Australia, like Canada, traces its roots back to English military law. ${ }^{87}$ When Australia was formed as a penal colony in 1788 , British military discipline applied to the force that accompanied the prisoners. ${ }^{88}$ In 1901, the various colonies formed a Commonwealth and the Australian Constitution provided the Federal Parliament the power, "[to] make laws for the peace, order and good government of the Commonwealth.... 89 Parliament later passed the Defence Act 1903 (Cth), which specified that the provisions of the British Army Act 1881 and Naval Discipline Act 1866 applied to the Australian Army and Navy respectively. ${ }^{90}$ When the Australian Air Force was founded on 31 March 1921, it was made subject to the Defence Act 1903. ${ }^{91}$ Following the formation of the various military services, the Australian military justice system generally utilised British legislation until $1985 .^{92}$

\subsubsection{The modern era}

In 1985, the Defence Forces Discipline Act (DFDA) amalgamated the three services 'and conferred upon them a comprehensive system of discipline law that reflected civilian criminal standards and processes. ${ }^{, 93}$ In the twenty years following the enactment of the DFDA, the Australian military justice system withstood numerous constitutional challenges before the High Court of Australia. ${ }^{94}$ Three cases-Re Tracey, Ex parte Ryan; Re Nolan and Another, Ex parte Young; and Re Tyler and Others, Ex parte Foley-examined whether the jurisdiction exercised by a military tribunal was appropriate in relation to the Constitution. ${ }^{95}$ In terms of civilianization, the Court examined whether the service tribunal-in this circumstance a court martial-was improperly exercising a (civilian) judicial power stip-

\footnotetext{
${ }^{87}$ See R Tracey, 'The Constitution and Military Justice' (2005) 28 UNSW LJ 426.

${ }^{88}$ See F B Healy, above $\mathrm{n} 15$.

${ }^{89}$ Ibid, 94.

${ }^{90}$ Ibid, 95.

${ }^{91}$ Ibid, 96.

92 Ibid, 93.

${ }^{93}$ Ibid, 96.

${ }^{94}$ See Tracey, above n 87, 429.

${ }^{95}$ See Healy, above n 15, 128; See also Re Tracey, Ex parte Ryan (1989) 166 CLR 518; Re Nolan and Another, Ex parte Young (1991) 172 CLR 460; Re Tyler and Others, Ex parte Foley (1994) 181 CLR 18.
} 
ulated in Chapter III of the Australian Constitution. ${ }^{96}$ In upholding the unique nature of military tribunals, the Court 'accepted that a service tribunal which was trying offences under [the DFDA] had all the characteristics of a Court exercising judicial power. ${ }^{\text {,97 }}$

The Australian military justice system enjoyed a 10 -year period free from High Court scrutiny until the 2004 case of Re Aird, which involved a service member charged with rape while on leave in Thailand. ${ }^{98}$ The Court narrowly held that in the circumstances, a court martial had jurisdiction to hear the charge against the accused. ${ }^{99}$

In terms of removing the commanding officer from the court martial process, Australia appeared to follow the lead set by Canada. Challenges to the UK and Canadian military justice system led the Chief of the Defence Force (CDF) to request an independent review of the Australian military justice system in the late 1990's. ${ }^{100}$ Recommendations from the 1997 Abadee Report resulted in various amendments that served to eliminate the ability of a convening authority to review the outcome of a court martial convened by that authority. ${ }^{101}$ Recommendations from a subsequent report in 2001 eventually led to the statutory establishment of the Director of Military Prosecutions (DMP) and Registrar of Military Justice (RMJ) in June 2006, following the enactment of legislation amending the Defence Force Discipline Act 1982. ${ }^{102}$ The establishment of these two positions in statute removed the prosecution discretion and convening authority of the chain of command. ${ }^{103}$ At this point, the amendments to the Australian court martial system retained the military character of the system. ${ }^{104}$ Indeed, in contrast to Canada and the UK, both the DMP and RMJ were military officers. ${ }^{105}$ Change towards a more civilianized model, however, would be forthcoming in the near

\footnotetext{
${ }^{96}$ See Healy, above n 15, 128. See also Commonwealth of Australia Act, 1900 (Imp), 63 \& 64 Victoria, c.12 (UK) (Australian Constitution).

97 Tracey, above n 87, 430 (referring to Re Tracey, Ex parte Ryan).

${ }^{98}$ See Re Aird (2004) 209 ALR 311; see also Mitchell \& Voon, above n 12, 396.

${ }^{99}$ See Mitchell \& Voon, above n 12, 407-408.

${ }^{100}$ Judge Advocate General, Defence Force Discipline Act: Report for the Period 1 January to 31 December 2003, (2003) para 33 (Australian JAG Report 2003).

${ }^{101}$ Ibid, para 29(a).

${ }^{102}$ J C S Burchett, Report of an Inquiry into Military Justice in the Australian Defence Force (July 2001) recc. 47 and 48 (to create DMP and RMJ respectively); Defence Legislation Amendment Act (No.2) 2005 (Cth) ss 188F, 188G.

${ }^{103}$ Australian JAG Report 2005, above n 12, paras 62, 82(c).

${ }^{104}$ Judge Advocate General, Defence Force Discipline Act: Report for the Period 1 January to 31 December 2006, (2006) paras 53, 54 (Australian JAG Report 2006).

${ }^{105}$ Ibid.
} 
future.

\subsubsection{The beginning of civilianization}

From 2003-2005, the Senate Foreign Affairs, Defence and Trade References Committee conducted the most comprehensive inquiry of the military justice system in Australia's history. ${ }^{106}$ The Senate Report is arguably the beginning of the 'civilianization era' in Australia. In its examination of service tribunals, the Committee examined developments in other Commonwealth countries such as the UK and Canada, noting that 'recent overseas developments also indicate that the current Australian disciplinary system is outdated and may not adequately protect Service personnel's rights.'107

Following submissions and testimony from the Australia JAG and other witnesses before the Committee, ${ }^{108}$ the Report made sweeping recommendations to the military justice system that included, inter alia, the abolishment of traditional courts martial to be replaced by a permanent military court. ${ }^{109}$ As will be discussed below, this attempt to civilianize the military justice system-some 8 years following the Senate's recommendations-has arguably resulted in a cautionary tale for those charged with developing and implementing military justice policy.

\subsubsection{The brief rise of the Australia Military Court}

The government agreed with the Senate's recommendation to abolish the traditional ad hoc courts martial and create a permanent military court. ${ }^{110}$ To that end, the Australian Parliament passed the Defence Legislation Amendment Act (DLAA) 2006 and the Australia Military Court (AMC) was established on 1 October 2007. ${ }^{111}$ In terms of the AMC's legal framework, the legislation creating

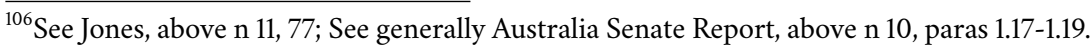

${ }^{107}$ Australia Senate Report, above n 10, para 5.45.

${ }^{108} \mathrm{Ibid}$, paras 5.8-5.18; 5.19-5.32.

${ }^{109}$ Australia Senate Report, above n 10, at li-liv.

${ }^{110}$ See Government of Australia, Department of Defence, Government Response to the Senate Foreign Affairs, Defence and Trade References Committee, Report on the Effectiveness of Australia's Military Justice System, October 2005 (Government Response), <http://www.defence.gov.au/mjs/docs/mji_government_response_4oct052.pdf> [accessed 21 August 2013].

${ }^{111}$ Defence Legislation Amendment Act 2006 (Cth) (DLAA 2006); See Government of Australia, Department of Defence, Changes to the Military Discipline System, <http://www.defence.gov.au/mjs/reform.htm> [accessed 21 August 2013] (DoD government website).
} 
the court specified that it was not a 'court' under Chapter III of the Australian Constitution but a 'service tribunal' under Article 51 (vi), the defence power. ${ }^{12}$

The AMC retained the character of a service tribunal. ${ }^{113}$ Its judges were military officers. The Registrar of the AMC (formerly the RMJ) referred charges to the court, and the DMP and the Director of Defence Counsel Services (DDCS) were respectively responsible for prosecuting and defending matters before a military judge alone or a military judge and jury. ${ }^{114}$ In supporting the military nature of the AMC, the explanatory memorandum outlining the legislation highlighted the requirements of deployability, a knowledge and understanding of military culture and credibility with members of the ADF as key 'philosophies and characteristics' of the court. ${ }^{115}$

\subsubsection{Lane v Morrison: the end of the AMC}

The AMC operated from 1 October 2007 until 26 August 2009. ${ }^{116}$ The latter date undoubtedly stands as a watershed moment in Australian military justice, when the High Court decided its first constitutional challenge against the legality of the AMC in Lane v Morrison. ${ }^{117}$ In Lane, the Court examined if the permanent military court established by the DLAA 2006 was improperly exercising the powers of a Chapter III (civilian) court. ${ }^{118}$ The Court determined that although the DLAA 2006 stated that the AMC was a 'service tribunal', the legislation also deemed it a 'court of record', thus closely resembling a civilian Chapter III court. ${ }^{119}$ The Court struck down the DLAA 2006 thus invalidating the AMC and all of its prior judgments. ${ }^{120}$

\footnotetext{
${ }^{112}$ DLAA (2006), above n 111, s114 (1) Note 1 and 2.

${ }^{113}$ See Explanatory Memorandum, Defence Legislation Amendment Bill 2006 (Cth), para 4 ('the AMC is a "service tribunal" under the DFDA...') (Explanatory Memorandum DLAA 2006).

${ }^{114}$ Ibid, para 62, 83 (military judges), para 103 (Registrar of the AMC); See also Government of Australia, Department of Defence, Australian Military Court-Fact Sheet, undated, 2 ('all prosecutions will be conducted through ...[the DMP]. A new Director of Defence Counsel Services provides legal representation for the accused'), <www.defence.gov.au/mjs/resources/AMC\%20fact\%20sheet.pdf> [accessed 31 Oct 13].

${ }^{115}$ Explanatory Memorandum DLAA 2006, above n 113, para 4.

${ }^{116}$ See DoD government website, above $\mathrm{n} 111$.

${ }^{117}$ Lane v Morrison (2009) 239 CLR 230 (Lane).

${ }^{118}$ See Press Release, High Court of Australia, Brian George Lane v Colonel Peter John Morrison HCA 29, 26 August 2009, <http://www.highcourt.gov.au/media/Lane_v_Morrison.pdf> [accessed 21 August 2013] (Press Release); See generally A Duxbury, 'The Curious Case of the Australian Military Court', (2010) 10 Ox Univ Common LJ 155.

${ }^{119}$ See Press Release, above n 118; Duxbury, above n 118, 181-182; see generally Lane, above n 117.

${ }^{120}$ See DoD Government website, above n 111.
} 


\subsubsection{The aftermath of Lane: a return to the old system (for now)}

The government was obviously left in a precarious position. With no service tribunal in place to address serious disciplinary cases, Parliament was forced to enact legislation to revive the 'traditional' court martial system. ${ }^{121}$ In 2010, the government announced that a new military court would be established not under the defence power but pursuant to Chapter III of the Constitution. ${ }^{122}$ The court-known as the Military Court of Australia (MCA)-would be a permanent court comprised of civilian judges with military experience. ${ }^{123}$ The legislation creating the court provided that all charges would be tried by judge alone with no military panel or jury, regardless of the seriousness of the offence. ${ }^{124}$

The debate over the bill was short lived with the calling of an election in July $2010 .{ }^{125}$ In the interim, the government passed further legislation to allow for the 'traditional' system of courts martial to act as the service tribunal for serious disciplinary offences in the ADF. ${ }^{126}$ Ironically, the traditional system of courts martial was later examined by the High Court whereby it expressed no concerns regarding its constitutionality. ${ }^{127}$

In 2012, the Australian Parliament later introduced the MCA Bill that was similar to that proposed in 2010. ${ }^{128}$ As with the previous bill, the MCA Bill 2012 provides for any service offence to be tried by judge (or judges) alone. ${ }^{129}$ Not surprisingly, the problems associated with the lack of a jury or panel has

${ }^{121}$ See Government of Australia, Department of Defence, Defence Annual Report 2010-2011, 220 (Defence Annual Report 2010-2011); Military Justice (Interim Measures) Act (No.1) 2009 (Cth) (2009 Military Justice Act).

${ }^{122}$ See Press Release, Attorney General for Australia, Establishment of the Military Court of Australia, 24 May 2010, <http://robertmcclelland.com.au/2010/05/24/establishment-of-the-military-court-ofaustralia $>$ [accessed 21 August 2013] (AG press release).

${ }^{123}$ See Parliament of the Commonwealth of Australia, House of Representatives, Explanatory Memorandum, Military Court of Australia Bill 2010 (Cth), paras 18-19 (Explanatory Memorandum MCA 2010).

${ }^{124}$ Ibid, para 93-94.

${ }^{125}$ See Letter from Senator Trish Crossin, Chair of the Senate Legal and Constitutional Affairs Legislation Committee to Senator the Honourable John Hogg, President of the Senate, 23 July 2010 (on file with author).

${ }^{126}$ Military Justice (Interim Measures) Amendment Act 2011 (Cth).

${ }^{127}$ See Haskins v Commonwealth of Australia (2011) 244 CLR 22 (Haskins) and Nicholas v Commonwealth of Australia [2011] HCA 29 (Nicholas).

${ }^{128}$ See Parliament of the Commonwealth of Australia, House of Representatives, Explanatory Memorandum, Military Court of Australia Bill 2012 (Cth), para 2 (Explanatory Memorandum MCA Bill 2012). Cf, Explanatory Memorandum MCA 2010, above n 123.

${ }^{129}$ Explanatory Memorandum MCA Bill 2012, above n 128, para 10. 
brought forth considerable criticism during committee study. ${ }^{130}$ Academics, practitioners and interest groups identified a likely constitutional challenge to the MCA based on section 80 of the Constitution. ${ }^{131}$ The Committee's final report, while recognising this limitation to the bill, recommended that it proceed through Parliament. ${ }^{132}$ Following the election in September 2013, it is unclear whether the MCA Bill 2012 will become law. ${ }^{133}$

\subsection{The United States}

It is against the backdrop of civilianization over the past twenty years that this paper now turns to developments in the US. In stark contrast to the three countries examined above, the American military justice system has remained generally unaffected by the recent trend away from a command-based model in the court martial system. ${ }^{134}$

\subsubsection{Mirroring the British Articles of War}

The American military justice system can be divided into two distinct eras: the period under the Articles of War enacted by the Continental Congress on 30 June 1775 until the enactment of the Uniform Code of Military Justice (UCMJ) in 1951 and the period from this date into the new millennium. ${ }^{135}$

\footnotetext{
${ }^{130}$ See Australia Defence Association, Submission to the Australian Senate on Legal and Constitutional Affairs, Submission to the Senate Legal and Constitutional Affairs Committee Concerning the Bills to Establish a Military Court of Australia, 16 September 2012, para 43 (Australia Defence Association submission); G Appleby \& J Williams, Submission to the Australian Senate on Legal and Constitutional Affairs, Submission: Inquiry into the Military Court of Australia Bill 2012 and Military Court of Australia (Transitional Provisions and Consequential Amendments) Bill 2012, 12 July 2012, 4 (Appleby \& Williams submission); A Street, Submission to the Australian Senate on Legal and Constitutional Affairs, Submission of Alexander Street, SC, 11 July 2012, para 9 (Street submission).

${ }^{131}$ See Street submission, above n 130, para 31; Australia Defence Force submission, above n 130, para 47. See generally Appleby \& Williams submission, above n 130, 3 (stating that 'the constitutional guarantees of the military accused should be the same as to other citizens').

${ }^{132}$ Parliament of Australia, Senate Foreign Affairs, Defence and Trade References Committee, Provisions of the Military Court of Australia Bill 2012 and the provisions of the Military Court of Australia (Transitional Provisions and Consequential Amendments) Bill 2012 (9 October 2012).

${ }^{133} \mathrm{~S}$ Cullen, 'Julia Gillard calls September 14 federal election', $A B C$ News, 31 January 2013, <http://www.abc.net.au/news/2013-01-30/julia-gillard-calls-september-14-federalelection/4491118> [accessed 21 August 2013].

${ }^{134}$ See generally Hansen, above $n 7$.

${ }^{135} \mathrm{~J} \mathrm{~S}$ Cooke, 'Introduction: Fiftieth Anniversary of the Uniform Code of Military Justice Symposium Edition', 165 Mil LR, 1, 2 (2000).
} 
As with Canada and Australia, the US adopted British military law. As such, the American Articles of War mirrored those from Great Britain. ${ }^{136}$ The various iterations of the American Articles of War 'provided for trial by courts-martial, although the jurisdiction and composition of these courts were modified from time to time.' ${ }^{137}$

\subsubsection{The inter-war years: reflecting on the military justice system}

Up until World War I, interest in the military justice system had been waning, but soon thereafter, the Acting Judge Advocate General of the Army expressed criticism of the military justice system because of numerous cases, which had handed out the death sentence to offenders without legal review by his office. ${ }^{138}$ Upon returning to his post, the Judge Advocate General quelled this dispute by defending the system thereby indirectly 'permit[ting] autonomy for local commanders in matters of military justice.' ${ }^{139}$ This 'Crowder-Ansell dispute' led to the critical question of whether 'the will of the commander or the rule of law [should] reign supreme in the American military justice system. ${ }^{140}$

\subsubsection{The UCMJ and the modern military justice system}

In comparison to other conflicts in which America was involved, World War II was fought by '[a] soldier [who was] a regular citizen' ${ }^{141}$ Many were appalled with the state of the military justice system and 'a hue and cry arose for reform.' ${ }^{142}$

This became the precursor to the second era of the American military justice system. In 1948, the Elston Act was enacted, which included a prohibition of unlawful command influence, automatic appellate review in certain cases and a Miranda-like warning-years before that historic case would be decided. ${ }^{143}$

The changes advanced by the Elston Act had only just entered into force when in 1948 Secretary of Defense James Forrestal appointed a committee led by Harvard Law Professor Edmund Morgan (who was a protégé of Ansell). ${ }^{144}$ The

\footnotetext{
${ }^{136}$ Ibid, 4.

${ }^{137}$ W T Cox III, 'The Army, the Courts and the Constitution: The Evolution of Military Justice' (1987) 118 Mil LR 1, 6.

${ }^{138}$ See Cox, above n 137, 9-10; Cooke, above n 135, 5-6.

${ }^{139}$ Cox, above n 137,10 .

${ }^{140}$ Ibid.

${ }^{141}$ Ibid, 11 .

${ }^{142}$ Ibid, 12.

${ }^{143}$ L J Morris, Military Justice: A Guide to the Issues (2010) 126.

${ }^{144}$ Ibid, 127; see also Cooke, above n 135, 7.
} 
committee, formally named 'The Uniform Code of Military Justice Committee,' was tasked to, inter alia, 'integrate the military justice system across the three services' and 'modernize the system to promote public confidence and protect the rights of the service member, without impeding the military function.' ${ }^{\text {,15 }}$ Ultimately, a bill was introduced in Congress in 1948. Following some minor changes-including changing the name of 'Judicial Council' to 'Court of Military Appeals'-and approximately 18 months of study and debate, President Truman signed the bill into law on 5 May 1950. ${ }^{146}$ The UCMJ went into effect on 31 May $1951 .{ }^{147}$

It has been suggested that the UCMJ in 1951 reflected certain aspects of civilianization in that the new Code was an effort to combine ... the old command-dominated military justice system and the civilian criminal justice system with its heavy emphasis on due process. ${ }^{\text {148 }}$

\subsubsection{Amendments to the UCMJ and civilianization}

Following the original enactment of the UCMJ in 1951, the American military justice system has not been without judicial scrutiny. Towards the end of the 'feeling out' period between 1951 and 1969, ${ }^{149}$ the Supreme Court issued a seminal ruling on the fledging system in O'Callahan $v$ Parker. ${ }^{150}$ From a comparative perspective, this case is strikingly similar to the Canadian Genereux case given that amendments to enhance the system were slated to go forward as the respective courts scrutinized the 'old' system. ${ }^{151}$

The Supreme Court did not look favourably on the military justice system in 1969. Indeed, " $[\mathrm{t}$ ] he military justice system was still seen as vastly different-and inferior. ${ }^{, 152}$ While the case primarily dealt with the nexus between the offender's military duties and the service offence, ${ }^{153}$ the Court was scathing in its general impressions of the military justice system. For instance, Justice Douglas, writing for the majority, bluntly stated, 'courts-martial as an institution is singularly inept

\footnotetext{
${ }^{145}$ Cox, above n $137,13$.

${ }^{146}$ Ibid, 14; see also Barry (2002), above n 14, 70-72.

${ }^{147}$ See Barry (2002), above n 14, 71.

${ }^{148}$ Cooke, above n 135, 8; see also Barry (2002), above n 14, 70; Hansen, above n 7, 427-428.

${ }^{149}$ See Cooke, above n 135, 10-13.

${ }^{150}$ O'Callahan v Parker, 395 U.S. 258 (1969).

${ }^{151}$ See Cooke, above n 135, 3; Pitzul and Maguire, above n 12, 9.

${ }^{152}$ Cooke, above n 135,3 .

${ }^{153}$ See Cox, above n 137, 21.
} 
in dealing with the nice subtleties of constitutional law. ${ }^{154}$ Notwithstanding this admonition, the Military Justice Act of 1968 'would do much to dispel such criticisms. $^{\text {,155 }}$

The 1975 decision in Schlenger $v$ Councilman ${ }^{156}$ was noteworthy in establishing the 'modern' military justice system as separate from the civilian system. ${ }^{157}$ As with Genereux in Canada, ${ }^{158}$ the Court validated the military justice system as a unique and fair system of justice. ${ }^{159}$ This notion of 'maturity' 160 was later reinforced by the Supreme Court in a number of cases including Weiss $v$ United States. ${ }^{161}$ It was thus observed that 'the Court's decisions indicate increased respect for military justice as a system of justice.'162

\subsubsection{The $50^{\text {th }}$ anniversary of the UCMJ and calls for change}

This 'period of stability ${ }^{\prime 163}$ in the American military justice system remained until the $50^{\text {th }}$ anniversary of the UCMJ. ${ }^{164}$ In 2001, the National Institute of Military Justice (NIMJ) - a nonprofit, nongovernmental organisation-sponsored a commission to 'examine the current operation of the Code and to evaluate the need for change.' 165 Unlike their allies in Canada, Australia and the UK, where calls for change were spurred by parliamentarians or the courts, this commission was chaired by retired Chief Judge Cox (of the United States Court of Appeals for the Armed Forces) with other members comprised of retired JAG officers and university professors. ${ }^{166}$ Following receipt of 250 comments and testimony from over 20 organisations or individuals, the Cox Commission Report was released in May 2001. ${ }^{167}$

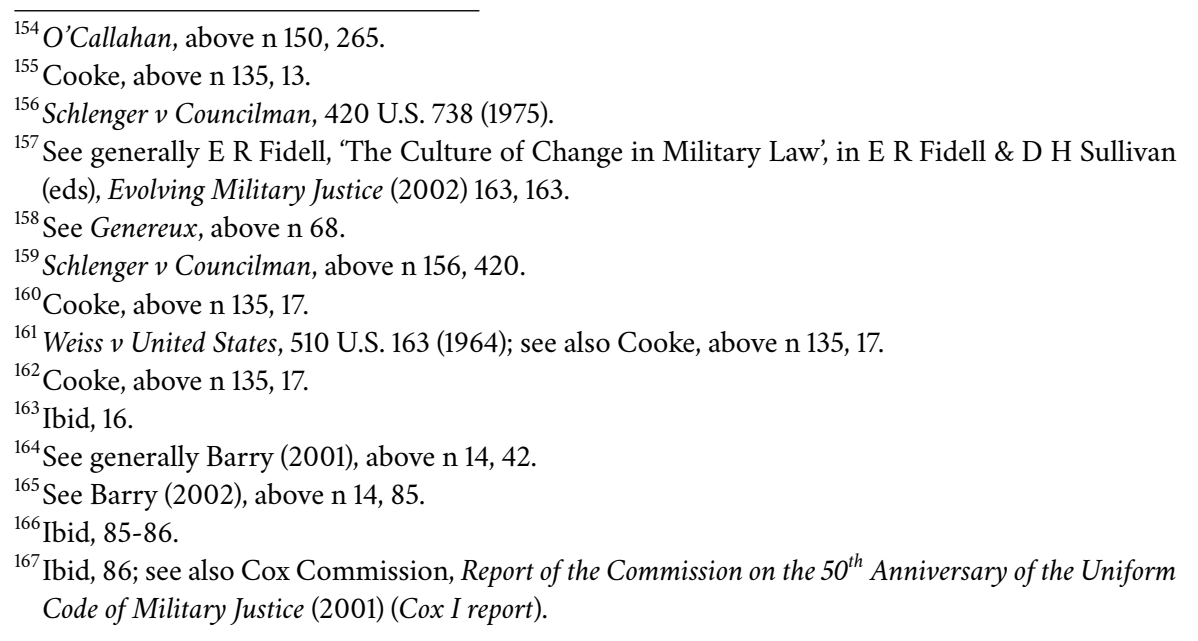


The Executive Summary identified the pretrial role of the convening authority to select court martial members as an area of concern and recommended increasing the independence of military judges, implementing additional protections in death penalty cases and repealing the rape and sodomy provisions of the UCMJ. ${ }^{168}$ Following release of its recommendations, the reaction of the military justice community appeared mixed. ${ }^{169}$ A second Cox Commission was established in 2009 and recommended changes to the military justice system that focused on appellate, trial procedure and investigative processes. ${ }^{170}$

\subsubsection{Recent cracks in the command-centric model}

The military justice system has also been examined by the executive and legislative branch in light of high-profile sexual assault cases. ${ }^{171}$ Allegations of sexual assault at a US Air Force's basic military training site have resulted in 12 confirmed or alleged victims of sexual assault since June $2011 .{ }^{172}$ In a statement to the House Armed Services Committee in January 2013, the Chief of Staff of the US Air Force stated that six accused had been court-martialled with four trials scheduled in the future. ${ }^{173}$

Further, in early 2013, a decision by a reviewing authority to dismiss the sexual assault conviction rendered by a court martial was met with a decision by the Secretary of Defence to examine the role of the convening authority (a function of the chain of command) in that particular case and its role in the military justice system generally. ${ }^{174}$ On 13 March 2013, the Senate Armed Services Subcommittee on Personnel heard testimony relating to sexual assault in the

\footnotetext{
${ }^{168}$ Barry (2002), above n 14, 98.

${ }^{169}$ See T Essex \& L Tate Pickle, 'A Reply to the Report of the Commission on the 50th Anniversary of the Uniform Code of Military Justice (May 2001): “The Cox Commission”' (2002) 52 Air Force L Rev 233, 264.

${ }^{170}$ See Cox Commission II, Commission on Military Justice, Report of the Commission of Military Justice (2009) (Cox II report) 3-5.

${ }^{171}$ See generally, US Senate Committee on Armed Services (Subcommittee on Personnel), 'Hearing to Receive Testimony on Sexual Assaults in the Military', 112 ${ }^{\text {th }}$ Cong., 13 March 2013, $<$ http://www.armed-services.senate.gov/imo/media/doc/13-10\%20-\%203-13-13.pdf> [accessed 2 November 2013] (Senate Armed Services Committee Hearing); Hagel letter, above n 13.

${ }^{172}$ US House of Representatives Armed Services Subcommittee on Personnel, $112^{\text {th }}$ Cong. 2, 23 January 2013 (statement of General Mark A. Welch, Chief of Staff, US Air Force) (Welch statement); see generally R Jervis, 'Sex Assault Scandal Casts a Pall Over Lackland AFB', USA Today, 20 July 2012, <http://usatoday30.usatoday.com/news/military/story/2012-07-19/lackland-airforce-sex-scandal/56332956/1> [accessed 14 October 2013].

${ }^{173}$ Welch statement, above n 172, 2.

${ }^{174}$ See Hagel letter, above $\mathrm{n} 13$.
} 
military where they examined, among other things, the role of the chain of command in the military justice system and reforms made in Canada and the UK. ${ }^{175}$ In early April 2013, the Secretary of Defense put forth the recommendation that Congress remove or amend certain authorities of the commanding officer to review the findings or sentence at court martial. ${ }^{176}$

Despite the recent interest in the US military justice system, ${ }^{177}$ as compared to its three allies, America remains the sole country to retain the commander as the key actor in court martial procedures (with Australia retaining the current system on an interim basis). ${ }^{178}$ The next section of the paper will compare the effect of civilianization in the countries noted above with a focus on the impact these changes have made to the chain of command's involvement in the court martial process.

\section{Civilianization and the chain of command}

\subsection{The United Kingdom: continuing the slide towards civilianization?}

Reforms in the UK continue to push its military justice system further towards civilianization, in no small part due to pressure of the ECtHR which eliminated the chain of command from the court martial process in the Findlay case in $1997 .{ }^{179}$

\subsubsection{The 1996 AFA, Findlay and the removal of the commander from the court martial process}

The Findlay decision had a chilling effect on the involvement of the chain of command in the military justice system. Prior to Findlay and the amendments in the 1996 AFA, the convening officer approved the charges and type of court martial, convened the court and appointed the president and members. ${ }^{180}$ The cumulative effect of the Findlay decision coupled with the legislative changes in

\footnotetext{
${ }^{175}$ See Senate Armed Services Committee hearing, above n 171, 59.

${ }^{176}$ See Hagel Statement, above $\mathrm{n} 13$.

${ }^{177}$ See generally Senate Armed Service Committee hearing, above n 171, Hagel letter, above n 13, Panetta letter, above $n 13$.

${ }^{178}$ See Hansen, above n 7, 421, 432; Military Justice (Interim Measures) Amendment Act 2011 (Cth), above $n 126$.

${ }^{179}$ See De Leon, above n 21, 267; Hansen, above n 7, 441 (where the author describes the effect of the AFA 1996); see generally Genereux, above n 68.

${ }^{180}$ See Hansen, above n 7, 439-440.
} 
the 1996 AFA created a quasi-civilian system such that 'these changes had the collective effect of significantly reducing the role of the commander in military justice and converging the military and civilian systems of justice. ${ }^{, 181}$

\subsubsection{The Armed Forces Act 2006: grappling with the role of the chain of command}

The debate surrounding the role of the chain of command in the military justice system persisted in Britain well into the new millennium. For instance, in testifying before a Parliamentary Committee studying the 2006 Armed Forces Bill, the Chief of the Air Staff was concerned, that 'the military justice system and the aspects of it which are covered in the Armed Forces Bill clearly recognise that difference from civilian life. ${ }^{182}$ In contrast, the Judge Advocate General (who is a civilian) conceded this point while stating that any amendments to the court martial system should mirror its civilian counterpart, opining that the court martial system should reflect the Crown Court in all respects except where there are good operational reasons for differences. ${ }^{\text {'183 }}$

In terms of the chain of command's involvement in the disciplinary process, one former Chief of the Defence Staff, Lord Boyce, objected to changing the role of the commanding officer in the British system, "[if] you diminish [the commanding officer's] authority or start to erode his authority you will get a fracture which is ultimately going to cause failure.' ${ }^{184}$

Despite Lord Boyce's warning, the ECtHR cases and the amendments in 1996 and 2006 resulted in the removal of the commander from the court martial process. $^{185}$ In terms of the administration of courts martial, the commanding officer has given way to a civilian administrator who is responsible for arranging the trial. ${ }^{186}$ The administrator selects the witnesses and any officers 'under the command of the higher-authority (i.e. the old convening authority) will not be selected as members of the court martial. ${ }^{\prime 187}$ Finally, the reviewing provisions

\footnotetext{
${ }^{181} \mathrm{Ibid}, 441$.

${ }^{182}$ Select Committee on the Armed Forces Bill, Volume I: Special Report, Together with Proceedings of the Committee, Oral and Written Evidence and Official Report, 2005-6, H.C. HC 828-I para 16 (UK) (British Parliamentary Report), <http://www.publications.parliament.uk/pa/cm200506/cmselect/cmarmed/828/82802.htm $>$ [accessed 14 October 2013].

${ }^{183} \mathrm{Ibid}$, para.76.

${ }^{184}$ British Parliamentary Report, above n 182, para 42.

${ }^{185}$ See Hansen, above n 7, 441-442 (describing the changes made through the AFA 1996).

${ }^{186}$ Ibid, 441.

${ }^{187}$ Ibid.
} 
following trial were also removed along with the corresponding authority to quash or substitute a sentence. ${ }^{188}$

It seems clear that the amendments in 2006 delineated 'serious matters'-to be kept free from the chain of command ${ }^{189}$-from 'discipline matters' that could be handled within the unit. ${ }^{190}$ In fairness to those charged with implementing the amendments, the long shadow cast by the ECtHR following a decade of criticism coupled with Parliamentary review may have led to a bill that inundated the military justice system with civilianized procedures in an effort to demonstrate that the system was ECHR compliant.

\subsubsection{Possible impacts of Findlay and AFA 1996, 2006 on the military justice system}

It is difficult to measure the degree to which the removal of the commanding officer from the court martial system has affected discipline. Scholars examining the civilianization of the British military justice system have commented favourably. ${ }^{191}$ One commentator noted, "[o]ne could reasonably believe that the Armed Forces Act 2006 is a significant step towards the establishment of a genuine self-contained system of military law and jurisdiction in Great Britain., ${ }^{192}$ Another commentator presents an interesting counterpoint that appears to underlie the civilianization dilemma, namely that "[the] expertise and awareness of the unique military environment, a traditional key component of military justice, has been significantly diminished. ${ }^{193}$ Given its modernised structure, the court martial system now restricts involvement from the chain of command: prosecutions are headed by a civilian Director of Service Prosecutions (DSP) (although the position could be filled by a military officer) and adjudicated by a civilian judge

\footnotetext{
${ }^{188}$ See AFA 1996, above n 34, s 16, sch. 5; see also AFA 2006, above n 48, s 272-275; J Blackett, Rant on the Court Martial and Service Law (2010) 8.02.

${ }^{189}$ See Ministry of Defence (UK), An Overview of the Service Justice System and the Armed Forces Act (undated) 3-4, <http://webarchive.nationalarchives.gov.uk/20110805174918/http://www.mod.uk/NR/rdonlyres/0D289346-3BAA-4446-9164-4600458D1CE9/0/AnOverviewoftheServiceJusticeSystemandtheArmedForcesAct.pdf $>$ [accessed 14 October 2013] ('COs retain discretion on how the majority of cases are handled, except those that are inherently serious').

${ }^{190}$ Ibid.

${ }^{191}$ See De Leon, above n 21, 292; Dhal, above n 3, 3.

${ }^{192}$ De Leon, above n 21, 292.

${ }^{193}$ Hansen, above n 7, 456.
} 
advocate. ${ }^{194}$ One could surmise that this aspect of the military justice system has become de facto civilian.

A related question regarding civilianization is whether there is an end-state other than that of a civilian criminal justice system. For example, despite the arguments that the civilianization of the system in 2006 was a positive trend, ${ }^{195}$ it arguably remains viewed as a flawed system. Supporting this notion is the reaction following the tragic events of 13 September 2003, when British soldiers captured and abused an Iraqi detainee. ${ }^{196}$ Three years later, seven soldiers were court-martialled for offences including manslaughter. ${ }^{197}$ One accused plead guilty and the remaining six were acquitted or the charges were dismissed by the judge advocate following closing of the prosecution's case. ${ }^{198}$ The outcome of the courts martial eventually led to a public inquiry and human rights organisations demanding a complete overhaul of the military justice system. ${ }^{199}$ Despite the fact that the judge advocate was a civilian and the chain of command presumably had no involvement in the convening, prosecution or adjudication of the cases, it has been asserted that ' $\mathrm{t}$ ] he military court-martial is an inherently self-serving institution with a tendency to operate as a damage limitation mechanism.200

Thus the trend towards civilianization could continue. Further amendments to the 2011 Armed Forces Act allow the DSP to delegate prosecutions to civilians-not solely to military officers as was previously the case. ${ }^{201}$ Whether or not ceding the prosecutorial and judicial function to civilians is in the best interests of fairness to the accused and discipline in the British Armed Forces may be debatable, but it appears clear that the UK military justice system is moving closer to a civilian criminal justice system model. ${ }^{202}$

\footnotetext{
$\overline{{ }^{194} \text { See AFA 2006, above n 48, s 362, } 364 .}$

${ }^{195}$ De Leon above n 21, 292.

${ }^{196} \mathrm{~N}$ Rasiah, 'The Court-Martial of Corporal Payne and Others and the Future Landscape of International Criminal Justice' (2009) 7 J Int'l Crim J 177, 195.

${ }^{197}$ Ibid.

${ }^{198}$ Ibid.

${ }^{199}$ Ibid, 178; see C Hawley, 'Baha Mousa inquiry reveals uncomfortable truths', $B B C$ News, 7 September 2011, <http://www.bbc.co.uk/news/uk-14790271> [accessed 14 October 2013]; see generally W Gage, The Baha Mousa Public Inquiry Report (2011).

${ }^{200}$ See Rasiah, above n 196, 195.

${ }^{201}$ Armed Forces Act 2011, c.52, 2011 s. 21 (UK) (AFA 2011).

${ }^{202}$ See generally M D Conway, 'Thirty-Ninth Kenneth J. Hodson Lecture in Criminal Law', (2012) 213 Mil LR 212 (where the Director General of the Army Legal Services outlines the various changes to the UK military justice system).
} 


\subsection{Canada: initial change then 'holding the line'}

In describing the impact of civilianization on modern military codes, one author has claimed, 'Canada was one of the first countries to lead this revolution.'203 In contrast to Australia, this 'revolution' was not self-imposed. ${ }^{204}$ As discussed above, the implementation of the Charter in 1982, coupled with the Supreme Court's decision in Genereux and the aftermath of the Somalia affair, forced the Canadian government to make changes to its military justice system. ${ }^{205}$

\subsubsection{The Dickson Report: balancing the needs of the chain of command with the right to a fair trial}

Just as the Elston Act served as an important pre-cursor for the changes to the 1950 UCMJ in the US, ${ }^{206}$ the Dickson Report one year prior to the legislative amendments in 1998 attempted to strike the delicate balance between involvement of the chain of command in the military justice system and Charter concerns. $^{207}$

Brian Dickson was a retired Chief Justice on the Supreme Court of Canada and a decorated veteran in World War II. ${ }^{208}$ Following the Somalia affair, he was tasked by the Minister of National Defence to produce a report examining the workings of the military justice system and make recommendations. ${ }^{209}$ Between the drama of the Somalia Inquiry hearings and the legislative changes made under Bill C-25, the 'Dickson Report' served as a measured independent view of the unique challenges of retaining the traditional powers of the commanding officer in consideration of the legal rights outlined in the Charter.

Dickson bluntly noted that " $t]$ he commanding officer is at the heart of the entire system of discipline. ${ }^{210}$ This statement may appear trite, yet in the shadow of the Somalia Inquiry it was possible that the military justice system would be radically restructured. ${ }^{211}$ Thus, when considering legislative amendments in relation to the commanding officer's role in the court martial process, the context

\footnotetext{
${ }^{203}$ Hansen, above n 7, 421.

${ }^{204}$ See generally Australia Senate Report, above n 10, ch 1 .

${ }^{205}$ See generally Pitzul \& Maguire, above n 12; Madsen, above n 69, 1-38.

${ }^{206}$ See Morris, above n 143, 125.

${ }^{207} \mathrm{~B}$ Dickson et al, Report of the Special Advisory Group on Military Justice and Military Police Investigation Services, 14 March 1997 (Dickson Report).

${ }^{208}$ See Madsen, above n 66, 147.

${ }^{209}$ See Dickson Report, above n 207, 2-3.

${ }^{210}$ Ibid, 12.

${ }^{211}$ See Madsen, above n 66, 148.
} 
in which these changes were made are important-the very existence of the military justice system was at stake.

\subsubsection{Bill C-25: modernizing the court martial system by introducing independent actors}

The 1999 changes to the military justice system served to eliminate the traditional role of the commanding officer from the court martial process. ${ }^{212}$ As noted earlier, the combined impact of Genereux and Bill C-25 eliminated the chain of command from any involvement in the selection of panel members, assignment of prosecutors and review of sentence. ${ }^{213}$ These changes included the creation of an independent (military) Director of Military Prosecutions (DMP) and (civilian) Court Martial Administrator. ${ }^{214}$ Once charges were referred to the DMP, the sole involvement of the chain of command in the court martial process was for the commanding officer and the next senior officer to provide a letter to the DMP explaining how the alleged offence impacted discipline. ${ }^{215}$ The decision to proceed (or not) with charges and the conduct of the prosecution rests solely with the DMP. ${ }^{216}$

\subsection{3 'Holding the line' in the military justice system: resisting civilianization}

Over the past decade, no major tensions between civilianizing the military justice system and the requirement for a separate system of justice to enforce discipline have arisen. For instance, there have been no Supreme Court challenges to the military justice system since Genereux in 1992 and the National Defence Act has not been significantly amended since 1998. ${ }^{217}$ Further, in the four draft bills introduced in Parliament to address the Lamer Report recommendations, the government appears to have consistently 'drawn the line'

\footnotetext{
${ }^{212}$ See Hansen, above n 7, 437.

${ }^{213}$ See Goetz, above $\mathrm{n} 11$.

${ }^{214} \mathrm{Ibid}$

${ }^{215}$ See Office of the Judge Advocate General (Canada), Director of Military Prosecutions, Director of Military Prosecutions-Policy Directive \# 005/99, Communication with Service Authorities, 18 March 2009, s 5, <http://www.forces.gc.ca/en/about-policies-standards-legal/comms-withservice-authorities.page> [accessed 14 October 2013].

${ }^{216}$ See Goetz, above n 11.

${ }^{217}$ Four omnibus military justice bills have been introduced into Parliament following the enactment of Bill C-25: Bills C-7, C-45, C-41 and C-15. See Bill C-7, above n 82.
} 
in resisting further changes relating to the chain of command's involvement in the military justice system and civilianization in general. ${ }^{218}$ These bills, including the one currently under study in Parliament, do not make any significant changes to the commanding officer's limited role in the court martial system. ${ }^{219}$ In contrast, the bill proposes to reinforce the unique military character of the system by introducing principles of sentencing with the aim 'to promote the operational effectiveness of the Canadian Forces by contributing to the maintenance of discipline, efficiency and morale. ${ }^{, 220}$

It is difficult to measure the impact upon discipline, if any, of removing the commanding officer from the court martial system. When examining the number of courts martial following the changes in 1999, the chain of command appeared to be uncomfortable with the new process. ${ }^{221}$ However, the consistent number of courts martial in the following decade suggests that the chain of command has subscribed to the new system and that the 1999 amendments have served to enhance the military justice system as a means to instil discipline. ${ }^{222}$ In this regard, a recent survey on the military justice system conducted by the Office of the Judge Advocate General stated, "[t]he [military justice system] as a whole effectively meets the needs of the chain of command. ${ }^{223}$

\subsection{Australia: in the throes of civilianization}

Australia appeared to have a well-functioning, constitutionally compliant military justice system before the Senate produced its 2005 report. ${ }^{224}$ The myriad of

\footnotetext{
${ }^{218}$ See generally Bills C-7, C-45 and C-41, above n 82; see also Bill C-15, above n 83.

${ }^{219}$ Ibid.

${ }^{220}$ Ibid, s 203.1(1).

${ }^{221}$ Office of the Judge Advocate General (Canada) Annual Report of the Judge Advocate General to the Minister of National Defence on the Administration of Military Justice in the Canadian Forces, 42 (JAG Annual Report 2001), <http://publications.gc.ca/collections/Collection/D1-16-2001E.pdf> [accessed 14 October 2013].

${ }^{222}$ Office of the Judge Advocate General (Canada) Annual Report of the Judge Advocate General to the Minister of National Defence on the Administration of Military Justice in the Canadian Forces, 15 (JAG Annual Report 2002), <http://www.collectionscanada.gc.ca/webarchives/20071126012359/http://www.forces.gc.ca/jag/office/publications/annual_reports/2002annualreport_e.pdf $>$ [accessed 14 October 2013].

${ }^{223}$ Office of the Judge Advocate General (Canada) Annual Report of the Judge Advocate General to the Minister of National Defence on the Administration of Military Justice in the Canadian Forces, 22 (2009-2010) (JAG Annual Report 2010), <http://www.forces.gc.ca/en/about-reports-pubsmilitary-law-annual-2009-10/index.page?> [accessed 14 October 2013].

${ }^{224}$ See Australia Senate Report, above n 10, paras 5.33-5.44.
} 
change in Australia in the intervening years represents a clear warning for allied military justice systems of the potential complexities of civilianization.

\subsubsection{The Australia Senate Report: recommendations for reform}

The Senate's examination of the military justice system did not truly come 'out of the blue'; rather, it was a response to a number of inquires into the military justice system that compelled the legislative branch to consider the issue. ${ }^{225}$ It was clear from the outset that the Senate was not receptive to the traditional role of the commander in the military justice system. The Committee gave little credence to the testimony of the Australian CDF when he stated that 'the control of the exercise of discipline, through the military justice system, is an essential element of the chain of command. ${ }^{226}$ Although the Committee, 'accept[ed] [the] basic premise' and the general validity of this proposition, it concluded that 'the weaknesses in the system ... all suggest that current structures are adversely affecting the rights of Service personnel. ${ }^{\text {227 }}$

The Committee appeared to defer to the opinion of civilian practitioners that subscribed to the opinion that service tribunals fundamentally lacked fairness, independence and impartiality due to 'the very nature of the military adjudicating the military' ${ }^{228}$ In the end, the Committee made 23 recommendations regarding the military justice system, which were prefaced by this statement, in bold typeface: "[a]ll recommendations are based on the premise that the prosecution, defence and adjudication functions should be conducted completely independent of the $\mathrm{ADF}^{229}$

\subsubsection{Fallout from Lane: moving further away from the chain of command}

Given the abbreviated tenure of the AMC following Lane, it is difficult to gauge what effect, if any, the revised court martial process had upon military discipline. However, in a 2008 speech, the former Chief of the Australian Army expressed his views on the dissonance between civilianized reforms to the military justice system and the distrust of the chain of command to administer this system: 'I was concerned with the implicit view shown by the recommendations that the

\footnotetext{
${ }^{225}$ Australia Senate Report, above n 10, para 1.4; see also Duxbury, above n 118, at 162 .

${ }^{226}$ Ibid, para 5.1.

${ }^{227}$ Ibid, para 5.2 .

${ }^{228}$ Ibid, para 5.19 .

${ }^{229}$ Ibid, li (Recommendations).
} 
military could not be trusted with the military justice system and it needed to be taken from us. ${ }^{230}$

Regardless of these concerns, the Australian military justice system is in the throes of civilianization. The 2012 proposed legislation creating the Military Court of Australia would eliminate the court martial system for trial by civilian judge (or judges) alone regardless of the seriousness of the offence. ${ }^{231}$ The legislation (as in 2010) also provides for an 'emergency provision' whereby the courts martial could be convened in operational theatres if and when necessary. $^{232}$

While the legislation has yet to be enacted, the bill stands as a cautionary tale for military justice reform. For instance, it is interesting to speculate what a service member accused of a serious offence would prefer-a court martial convened by the RMJ with the requisite military judge and panel, or trial before a civilian judge with no benefit of a jury. Further, the notion of a court martial on 'stand-by' for operational reasons risks a significant number of years passing before military prosecutors and military judges would be called upon to prosecute and adjudge a service member for what could be a serious service offence. ${ }^{233}$ Despite these perceived shortcomings, the CDF was a strong proponent of the MCA Bill 2012 before Senate Committee hearings in September 2012..$^{234}$

In light of submissions before the Senate Committee as to the likelihood of constitutional challenges to the right to be tried by a jury, ${ }^{235}$ it is debatable if discipline and fairness to the accused are best served by creating a new civilianized

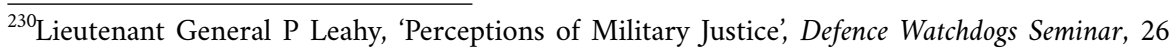
November 2008 (on file with author).

${ }^{231}$ See Explanatory Memorandum MCA Bill 2012, above n 128, para 10; Military Court of Australia Bill 2012 (Cth), s 65 (MCA Bill 2012).

${ }^{232}$ Explanatory memorandum MCA Bill 2012, above n 128, para 8.

${ }^{233}$ See generally Returned and Services League of Australia, Submission to the Inquiry by the Senate Legal and Constitutional Affairs Committee into the Military Court of Australia (undated) (Returned and Services League submission); G Early, Inspector General Australian Defence Force, Submission to the parliamentary inquiry into the Military Court of Australia Bill and the Military Court of Australia (Transitional Provisions and Consequential Amendments) Bill 2012 s 4(b) (IG submission).

${ }^{234}$ See Submission of General D J Hurley, Chief of the Defence Force, Submission to the Senate Legal and Constitutional Affairs Committee on the Military Court of Australia Bill 2012 and the Military Court of Australia (Transitional Provisions and Consequential Amendments) Bill 2012 (CDF submission).

${ }^{235}$ See Street submission, above n 130, para 9; IG submission, above n 233, s 4(a); Submission of Associate Professor A Duxbury, Dr R Livoja and Associate Professor M Groves, Submission to the Senate Standing Committee on Legal and Constitutional Affairs: Inquiry into the Military Court of Australia Bill 2012 and the Military Court of Australia (Transitional Provisions and Consequential Amendments) Bill 2012, 6 (Duxbury submission). 
system. Indeed, one could take the view that the current system is compliant with both the Australian Constitution and international conventions. ${ }^{236}$ In the end, whatever form the Military Court of Australia will take, prudence is recommended for any further iteration of the bill should the 2012 version not become law. The uniqueness of a military justice system as sui generis does not preclude adopting elements of the civilian criminal justice system to enhance the fairness and transparency of courts martial. However, caution is advised when considering the impact of importing civilian criminal justice practices to a military disciplinary system under the assumption that the former is the standard to which the latter must aspire. This premise was best captured in the written submission of the Inspector General of the ADF before the Senate Committee. He emphasised that the military and civilian justice systems are divergent in a key respect in that the former has the primary role to assist the chain of command in maintaining order and discipline in the ADF. ${ }^{237}$

Amongst the four countries examined in this paper, the US stands alone in retaining the 'traditional' command-centric military justice system. While the Uniform Code of Military Justice has withstood major reform for some time, ${ }^{238}$ it appears that the US military justice system could be on the precipice of the 'second wave' of civilianization.

\subsection{The United States: entering the second era of civilianization?}

While the US has been criticised in academic circles for not 'modernizing' their military justice system in step with their allies, ${ }^{239}$ this paper argues a counterpoint: the American military justice system has struggled with civilianization some 20 years before their allies and has not faced the external pressures experienced in the UK, Canada and Australia. ${ }^{240}$

In comparison with their allies, the US' modern era of military justice reform

\footnotetext{
${ }^{236}$ See generally Duxbury submission, above n 235, 1-2; Australia Defence Association, Submission to the Senate Legal and Constitutional Affairs Committee Concerning the Bills to Establish a Military Court of Australia (16 September 2012), para 14.

${ }^{237} \mathrm{IG}$ submission, above $\mathrm{n} 233$, at para 2.

${ }^{238}$ See Barry (2001), above n 14, 45.

${ }^{239}$ See Hansen, above n 7, 421-422; see also E R Fidell, 'A Worldwide Perspective Change in Military Justice', in E R Fidell \& D H Sullivan (eds), Evolving Military Justice (2002) 209, 210.

${ }^{240}$ See Karlen, above n 5, 60; see also Hansen, above n 7, 421-422; Hodson, above n 5, 53; see generally Everett, above n 1; Sherman, above n 2.
} 
began following World War II. ${ }^{241}$ In terms of the role of the commander in relation to the court martial process, the Elston Act in 1948 and the UCMJ ${ }^{242}$ in 1950 ushered in the 'modern military justice system in the United States.'243

Arguably, civilianization was once again on the agenda with the enactment of the Military Justice Act of $1968 .^{244}$ The theme of civilianization was further evident with the enactment of the Military Rules of Evidence in 1980: " $t$ t]he adoption of the military rules accomplished the goal of further legitimizing the military justice system by grounding it when possible on established federal practices...245 Finally, the promulgation of the Military Justice Act of 1983 further points toward civilianization with the extension of the Supreme Court's ability to hear matters from the Court of Military Appeals. ${ }^{246}$ These legislative initiatives did not fundamentally alter the command-centric focus of the chain of command in relation to court martial procedures, unlike what would later befall the UK, Canada and Australia. ${ }^{247}$

In comparison with countries noted above, it appears the US is not 'lagging behind' in terms of modernization, but was the forerunner in considering the role of the commander in its military justice system.

Despite the relative stability in its military justice system over the past 60 years, recent events suggest that the role of the commanding officer in the US court martial system may be reformed. ${ }^{248}$ As noted earlier in this paper, a series of high-profile events related to the military justice system has caused the legislative and executive branch to examine the current structure in detail. ${ }^{249}$

From a comparative perspective, during a March 2013 Senate Armed Services Subcommittee hearing studying sexual assault in the military, one senator observed the decision in Great Britain and Canada to remove certain historical responsibilities from the chain of command and questioned if such reform would be problematic in the US military justice system. ${ }^{250}$ The Judge Advocates'

\footnotetext{
${ }^{241}$ Morris, above n 206, 125-126.

${ }^{242}$ Ibid, 127-128.

${ }^{243}$ Barry (2001), above n 14, 42.

${ }^{244}$ See Morris, above n 206, 135.

${ }^{245} \mathrm{Ibid}, 137$.

${ }^{246}$ Ibid, 137-138.

${ }^{247}$ Ibid, 135-139.

${ }^{248}$ See generally Senate Armed Services Committee Hearing, above n 171; Hagel Statement, above n 13.

${ }^{249}$ See Mulrine, above n 13; Panetta letter, above n 13; Hagel letter, above n 13; Senate Armed Services Committee Hearing, above n 171; Hagel statement, above n 13.

${ }^{250}$ See Senate Armed Services Committee hearing, above n 171, 59.
} 
General from the Armed services and the Acting General Counsel generally supported the role of the commanding officer in the court martial system or were silent on the issue. ${ }^{251}$

In the end, recommended changes to the UCMJ came less than one month following testimony of the DoD Acting General Counsel before the same Senate subcommittee, as the Secretary of Defense announced recommendations to Congress to amend the convening authority's ability to review sentences in two significant ways. ${ }^{252}$ First, the discretion for a convening authority to set aside a conviction for serious offences would be removed. ${ }^{253}$ Further, any changes made by a convening authority to a court martial finding or sentence would require written reasons. ${ }^{254}$

In contrast with its allies and while there appear to be fissures in the historical traditions of the commanding officer in the American military justice system, those responsible for superintending military justice have been steadfast in their support and confidence in this 'traditional model. ${ }^{255}$ While it could be debated whether or not the US has or will enter a 'second wave' of civilianization, all four countries examined in this paper continue to incorporate civilian criminal justice procedures into their respective military justice systems. The next section of the paper offers some recommendations in this regard.

\section{Recommendations}

\subsection{Canada and Great Britain: study the impact of civilianization}

Given the transformation of the Canadian military justice system over the past decade, it would be beneficial to study the impact of removing the chain of

\footnotetext{
${ }^{251}$ See Senate Armed Services Committee Hearing, above n 171, 42, 59 (statement of Lieutenant General D Chipman, Judge Advocate General of the Army); Senate Armed Services Committee Hearing, above n 171, 46-47 (statement of Major General V Ary, Judge Advocate to the Commandant of the Marine Corps).

${ }^{252}$ See Hagel statement, above n 13; Senate Armed Services Committee hearing, above n 171, 42-44 (statement of Acting General Counsel R Taylor).

${ }^{253}$ Ibid.

${ }^{254}$ Ibid.

${ }^{255}$ See e.g. Senate Armed Services Committee Hearing, above n 171, 52-53 (Statement of Lieutenant General Richard Harding, Judge Advocate General of the Air Force), 53-54 (Statement of Vice Admiral DeRenzi, Judge Advocate General of the Navy and Statement of Major General Ary, Judge Advocate to the Commandant of the Marine Corps).
} 
command from the court martial system and the consequences, if any, on discipline and its relationship to operational effectiveness. As part of his statutory role to superintend the administration of the military justice system, the JAG must table a report to Parliament each fiscal year. ${ }^{256}$ Traditionally, the report examines a number of issues within the military justice system, including a qualitative survey that examines the views of the chain of command to identify any systemic issues of concern. ${ }^{257}$

Following the 1999 amendments, one survey indicated some confusion about the role of the chain of command in referring charges and convening courts martial. $^{258}$ However, that survey (in 2000) and subsequent surveys conducted in 2007 and 2010 show that respondents took the view that the military justice system met the needs of the chain of command to instil discipline. ${ }^{259}$

While the respective reports indicated that the chain of command is generally satisfied that the military justice system-as a whole-meets the needs of the chain of command, ${ }^{260}$ further study is required regarding the court martial system. For instance, all three surveys indicate that court martial proceedings are unduly administrative. ${ }^{261}$ It is unclear whether these comments are related to the relative lack of involvement of the chain of command once charges are preferred or some other factor.

In this context, given the relative stability in the number of courts martial in recent history coupled with the conclusion of combat operations in Afghanistan, ${ }^{262}$ it is recommended that the JAG conduct a more detailed study to capture the chain of command's views regarding the commanding officer's role in the court martial process. In particular, information pertaining to whether

\footnotetext{
${ }^{256}$ National Defence Act, R.S.C., 1985, c. N-5, s 9.3(2) (Canada).

${ }^{257}$ See e.g. Office of the Judge Advocate General, Annual Report of the Judge Advocate General to the Minister of National Defence on the Administration of Military Justice in the Canadian Forces (2007-2008), 16 (JAG Annual Report 2008).

${ }^{258}$ See JAG Annual Report 2001, above n 221, 42.

${ }^{259}$ See ibid; Office of the Judge Advocate General, Annual Report of the Judge Advocate General to the Minister of National Defence on the Administration of Military Justice in the Canadian Forces (2006-2007), 17 (JAG Annual Report 2007); see JAG Annual Report 2010, above n 223, 22.

${ }^{260}$ See JAG Annual Report 2001, above n 221, 42; JAG Annual Report 2007, above n 259, 17; JAG Annual Report 2010, above n 223, 22.

${ }^{261}$ See JAG Annual Report 2010, above n 223, 22; See JAG Annual Report 2001, above n 221, 42; JAG Annual Report 2007, above n 259, 17.

${ }^{262}$ See e.g. JAG Annual Report 2008, above n 257, 82. See also S Sachs, 'Canadian Troops Formally Handover Kandahar Battlefield to U.S. Forces', The Globe and Mail, 5 October 2011, <http://www.theglobeandmail.com/news/world/asia-pacific/canadian-troops-formallyhandover-kandahar-battlefield-to-us-forces/article2086777/> [accessed 30 October 2013].
} 
or not the amendments have strengthened or weakened the perceived ability of the commanding officer to maintain discipline could provide valuable insight in determining if the modified role of the chain of command in the court martial process has served to impact operational effectiveness. Finally, additional surveys with the Canadian Military Prosecution Service and legal officers serving in regional offices who advise commanding officers would also capture any recommendations in relation to the potential involvement of the chain of command in the court martial process once charges are laid.

A similar recommendation applies to the British military justice system. The multitude of changes following the Findlay decision in 1997 and the enactment of the AFA 1996 and 2006 have transformed the role of the commanding officer in the court martial process. ${ }^{263}$ It is unclear whether such changes are perceived positively by the chain of command or, more importantly, balance the interests of discipline and operational effectiveness with fairness toward the accused. To that end, an internal or independent review to examine the impact of the changes on the British military justice system in light of the 1996 and 2006 amendments is recommended. Given the tenor of civilian-like changes in the military justice system over the past decade, an independent review could focus its recommendations on how to integrate civilian authorities within the military milieu while examining if the modified system should allow for some involvement by the chain of command in the court martial process.

\subsection{Australia and the United States: consider modifications to the current system}

Australia is clearly trending towards the adoption of a civilianized military justice model. While the Lane decision in 2009 required interim legislation to re-establish the traditional court martial system, the proposed Military Court of Australia is arguably not a better system than the more 'traditional' system currently in place. Indeed, the current system was not viewed negatively by the High Court in 2010. ${ }^{264}$ Given the tumultuous recent history of military justice reform in Australia, perhaps the best advice can be gleaned from the current Australian DMP, who stated that the military discipline system would not survive should the MCA Bill 2012 be struck down on constitutional grounds. ${ }^{265}$ In light

\footnotetext{
${ }^{263}$ See Hansen, above n 7, 441; Blackett, above n 188, 4.02, 5.142.

${ }^{264}$ See Haskins, above n 127, para 21; Nicholas, above n 127.

${ }^{265}$ Brigadier L A McDade, Director of Military Prosecutions, Submission to the Inquiry into the Military Court of Australia Bill 2012 and the Military Court of Australia (Transitional Provisions and
} 
of this expected constitutional challenge, perhaps a re-examination of the MCA Bill 2012 is in order should it not pass into law.

In contrast, the US is currently reviewing the role of the chain of command in the court martial process both on deployed operations and in the context of sexual assault cases. ${ }^{266}$ Pending recommendations and potential legislative amendments on these issues, ${ }^{267}$ the role of the commanding officer could change in the coming months. ${ }^{268}$ However, based upon the recent Senate subcommittee hearings and statement by Secretary of Defense Hagel, ${ }^{269}$ it does not appear that the 'traditional' role of the commanding officer will be radically altered. ${ }^{270}$ When considering potential changes to the role of the commanding officer in the American military justice system, an in-depth study on comparative practices amongst 'Anglo-American' allies is recommended to fully understand the possible impact of altering the traditional role of the chain of command in relation to discipline in the American context.

\subsection{Establishing an Allied Military Justice Committee}

One recurring theme throughout this paper has been that every country examined above has cited the other in some regard. ${ }^{271}$ Despite this perceived reliance on comparative military law, it is proposed that legislators and those groups advocating reform must approach this exercise with great caution. For instance, academics may correctly point to the Genereux decision as a watershed moment in Canadian military justice but fail to appreciate the political climate surrounding Bill C-25 and its impact on legislative reform. ${ }^{272}$ In other cases, many academics are understandably unfamiliar with comparative military justice systems. ${ }^{273}$

Given the scope of changes discussed above, there appears to be a need for those charged with the superintendence of military justice systems in those

Consequential Amendments) Bill 2012 (13 July 2012).

${ }^{266}$ See Senate Armed Services Committee Hearing, above n 171; Panetta letter, above n 13; Hagel letter, above n 13; Hagel statement, above n 13.

${ }^{267}$ See Panetta letter, above n 13; Hagel statement, above n 13.

${ }^{268}$ See Hagel statement, above n 13.

${ }^{269}$ See Hagel Statement, above n 13; Senate Armed Services Committee Hearings, above n 171.

${ }^{270} \mathrm{Ibid}$; see generally Senate Armed Services Committee Hearings, above n 171 (where numerous TJAG's were supportive of the command-centric military justice system).

${ }^{271}$ See e.g. Australia Senate Report, above n 10, paras 5.45-5.67 (citing developments in Canada, the UK and the US); Cox I Report, above n 167, fn 4 (where the Report references the Findlay and Genereux cases as a catalyst for change in the UK and Canada respectively).

${ }^{272}$ See Madsen, above n 66, 144-150.

${ }^{273}$ See De Leon, above n 21, 266. 
countries to be aware of significant legislative or judicial decisions amongst the 'Anglo-American'274 countries. In this regard, it is proposed that these four countries form an ad hoc Military Justice Committee to keep appraised of developments in their respective countries. ${ }^{275}$ While one academic has proposed a similar idea to include civilian judges and academics, ${ }^{276}$ this paper proposes a slightly modified recommendation with the Committee limited to uniformed military justice practitioners charged with advising their respective Judge Advocates' General (or his/her equivalent) on strategic military justice policy. ${ }^{277}$ This would allow military justice experts to gain an in-depth view of reform from the policy-makers themselves and therefore benefit from the context in which the reforms are proposed.

\section{Conclusion}

It is unquestionable that the US and their 'Anglo-American"278 allies have travelled different paths in attempting to reconcile the need for discipline in an armed force with that of ensuring that an accused is provided with fair and due process. While academics have cited the lack of change in the American military justice system when compared to its allies, ${ }^{279}$ further examination reveals that it was the US, not its allies, that underwent a significant period of civilianization some 20 years before the term arguably became in vogue across military justice circles. ${ }^{280}$ The pace of reform over the past 20 years calls into question whether or not this wave of civilianization threatens the very existence of the 'Anglo-American ${ }^{281}$ military justice systems. While numerous reports in these countries subscribe to the notion of the commander as the "heart of discipline, ${ }^{282}$ it appears that such notion

\footnotetext{
${ }^{274}$ See Dhal, above $n 3$.

${ }^{275}$ See Fidell, above n 239, at 216 ('[m]ilitary justice experts, including judges, civilian practitioners, and academics, should meet more often').

${ }^{276} \mathrm{Ibid}$

${ }^{277}$ See Office of the Judge Advocate General (Canadian Forces), Military Law, <http://www.forces.gc.ca/en/about-org-structure/judge-advocate-general-office.page > [accessed 30 October 2013] (describing the various directorates of the Office of the Judge Advocate General).

${ }^{278}$ See Dhal, above $n 3$.

${ }^{279}$ See generally Hansen, above n 7, 452; Fidell, above n 239, 210 (noting that US jurisprudence does not follow international developments in military justice).

${ }^{280}$ See generally Everett, above n 1; Sherman, above n 2; Karlen, above n 5; Hodson, above n 5.

${ }^{281}$ See Dhal, above $n 3$.

${ }^{282}$ See Manual of Service Law, above n 9, 1-1-2; Dickson Report, above n 207, 12.
} 
could be at risk should this trend of civilianization continue. Whether or not the US will retain its current system has yet to be determined; but those entrusted with the superintendence of the military justice systems in the aforementioned countries would be wise to pay heed to the effect of civilianization among their closest allies and to question whether such reform is in the best interests of discipline and fairness to the accused. 